\title{
Organic molecular markers and signature from wood combustion particles in winter ambient aerosols: aerosol mass spectrometer (AMS) and high time-resolved GC-MS measurements in Augsburg, Germany
}

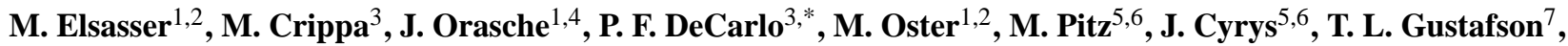 \\ J. B. C. Pettersson ${ }^{7}$, J. Schnelle-Kreis ${ }^{1}$, A. S. H. Prévôt ${ }^{3}$, and R. Zimmermann ${ }^{1,2}$ \\ ${ }^{1}$ Joint Mass Spectrometry Centre, Cooperation Group Comprehensive Molecular Analytics, Helmholtz Zentrum München, \\ Ingolstädter Landstr. 1, 85764 Neuherberg, Germany \\ ${ }^{2}$ Joint Mass Spectrometry Centre, Universität Rostock, Institut für Chemie, Lehrstuhl für Analytische Chemie, \\ Dr.-Lorenz-Weg 1, 18059 Rostock, Germany \\ ${ }^{3}$ Laboratory of Atmospheric Chemistry, Paul Scherrer Institute, 5232 Villigen PSI, Switzerland \\ ${ }^{4}$ Department of Sedimentology \& Environmental Geology, Georg-August-University Göttingen, 37077 Göttingen, Germany \\ ${ }^{5}$ Helmholtz Zentrum München, German Research Center for Environmental Health, Institute of Epidemiology II, 85764 \\ Neuherberg, Germany \\ ${ }^{6}$ University of Augsburg, Environment Science Center, 86159 Augsburg, Germany \\ ${ }^{7}$ Department of Chemistry, University of Gothenburg, 41296 Gothenburg, Sweden \\ * now at: Department of Civil Architectural and Environmental Engineering, Drexel University, 19104 Philadelphia, PA, USA
}

Correspondence to: J. Schnelle-Kreis (juergen.schnelle@helmholtz-muenchen.de)

Received: 23 December 2011 - Published in Atmos. Chem. Phys. Discuss.: 10 February 2012

Revised: 19 June 2012 - Accepted: 19 June 2012 - Published: 16 July 2012

\begin{abstract}
The impact of wood combustion on ambient aerosols was investigated in Augsburg, Germany during a winter measurement campaign of a six-week period. Special attention was paid to the high time resolution observations of wood combustion with different mass spectrometric methods. Here we present and compare the results from an Aerodyne aerosol mass spectrometer (AMS) and gas chromatographic - mass spectrometric (GC-MS) analysed $\mathrm{PM}_{1}$ filters on an hourly basis. This includes source apportionment of the AMS derived organic matter $(\mathrm{OM})$ using positive matrix factorisation (PMF) and analysis of levoglucosan as wood combustion marker, respectively.

During the measurement period nitrate and OM mass are the main contributors to the defined submicron particle mass of AMS and Aethalometer with $28 \%$ and $35 \%$, respectively. Wood combustion organic aerosol (WCOA) contributes to OM with $23 \%$ on average and $27 \%$ in the evening and night time. Conclusively, wood combustion has a strong influence on the organic matter and overall aerosol composition.
\end{abstract}

Levoglucosan accounts for $14 \%$ of WCOA mass with a higher percentage in comparison to other studies. The ratio between the mass of levoglucosan and organic carbon amounts to 0.06 .

This study is unique in that it provides a one-hour time resolution comparison between the wood combustion results of the AMS and the GC-MS analysed filter method at a $\mathrm{PM}_{1}$ particle size range. The comparison of the concentration variation with time of the PMF WCOA factor, levoglucosan estimated by the AMS data and the levoglucosan measured by GC-MS is highly correlated $\left(R^{2}=0.84\right)$, and a detailed discussion on the contributors to the wood combustion marker ion at mass-to-charge ratio 60 is given. At the end, both estimations, the WCOA factor and the levoglucosan concentration estimated by AMS data, allow to observe the variation with time of wood combustion emissions (gradient correlation with GC-MS levoglucosan of $R^{2}=0.84$ ). In the case of WCOA, it provides the estimated magnitude of wood combustion emission. Quantitative estimation of the 
levoglucosan concentration from the AMS data is problematic due to its overestimation in comparison to the levoglucosan measured by the GC-MS.

\section{Introduction}

Ambient organic aerosol is of high interest due to its effect on climate and human health (IPCC, 2007; Lohmann and Feichter, 2005; Pope and Dockery, 2006). During the winter season wood combustion (WC) is one of the major sources of organic aerosol in Europe (Puxbaum et al., 2007). Besides primary particles consisting of a complex mixture of soot, inorganic and organic matter (OM), WC additionally emits a considerable amount of volatile organic compounds (VOCs), some of which are known to be secondary organic aerosol (SOA) precursors (Grieshop et al., 2009; Heringa et al., 2011). WC has an important influence on aerosol composition. Nevertheless, its significance may grow with the anticipated increase in the use of renewable energy sources. Therefore, it is important to develop tools to quantify the contribution of WC to air pollution.

Nowadays, several novel offline and online measurement systems make the observation of the highly dynamic process of WC emission events and their contribution to the ambient aerosol possible. The offline methods, for instance the analysis of filter samples with gas chromatography (GC), provide quantitative and qualitative results of WC markers such as levoglucosan, potassium and phenolic compounds (Sandradewi et al., 2008a; Svane et al., 2009; Simoneit, 2002; Cass, 1998). Some of these WC markers and several statistical source apportionment methods (Viana et al., 2008) like positive matrix factorisation (PMF) are also the basis for the online WC emission analysis. Recently, some online hightime resolution instruments became available, for instance the aerosol mass spectrometer with subsequent statistical analyses (e.g. Lanz et al., 2008; Ulbrich et al., 2009). In addition, multi-wavelength light-absorption measurements were used to determine the contribution of wood combustion particles (Sandradewi et al., 2008a, b). Consequently, it is of high interest to know how well these methods agree. Other studies have compared source apportionment methodologies (Favez et al., 2010; Kim and Hopke, 2004).

The present work is primarily focused on the measurements performed in Augsburg, Germany, using an Aerodyne aerosol mass spectrometer (AMS) during a winter measurement campaign in 2010. This campaign was designed to determine the WC influence on the ambient aerosol with different highly time-resolved online and offline mass spectrometric methods in a medium sized Central European city during wintertime.

We specifically compare WC organic matter derived from PMF analysis of AMS data and levoglucosan concentrations from GC-MS measurements. The signal of mass-to-charge ratio $(\mathrm{m} / \mathrm{z}) 60$ is of major interest due to its potential as a WC marker ion in electron ionisation mass spectrometry, like the AMS (e.g. Alfarra et al., 2007 and Schneider et al., 2006). The novelty of the presented approach is the comparison of AMS data and PMF analysis with results from offline $\mathrm{PM}_{1}$ filter measurements under ambient conditions on a one-hour basis. Recently, other ambient studies (Aiken et al., 2009; Favez et al., 2010) compared the GC-MS and AMS methods in a time resolution range of $12-24 \mathrm{~h}$ and on a $\mathrm{PM}_{2.5}$ filter measurement basis. In an emission study by Lee et al. (2010) wood burning results obtained with these methods were compared on an approximately one-hour resolution $\mathrm{PM}_{2.5}$ filter measurement basis. In this work, the concurrent filter and AMS data will be analysed to carry out the comparison in a similar particle size range with a high time resolution; this offers the opportunity to study the dynamic impact of WC on the organic aerosol composition (for example, diurnal variation and levoglucosan to organic carbon (OC) ratio).

Additional online mass spectrometers were run during this campaign. They include an Alkali AMS (Svane et al., 2004,2009 ) for online potassium and sodium determination, a single-particle thermal-desorption laser mass spectrometer (TD-REMPI-SP-ToF-MS) (Bente et al., 2006) for polycyclic aromatic hydrocarbon (PAH) detection on single particles (Oster et al., 2011) and an AMS for local source apportionment set up in the mobile atmospheric pollution laboratory "MOSQUITA" ("Measurements Of Spatial QUantitative Imissions of Trace gases and Aerosols", Bukowiecki et al., 2002; Mohr et al., 2011). These data are presented in other studies (e.g. Oster et al., 2011).

\section{Methods}

\subsection{General}

The campaign was carried out in the city of Augsburg, Germany for a six-week winter period from 31 January to 12 March 2010. Augsburg is located in the southwest of Bavaria, Germany, and has about 260000 inhabitants. The city and the surrounding terrain are flat and covered with mainly multistorey buildings with chimneys. Augsburg was subject to a number of ambient (Gu et al., 2011) and health studies (Löwel et al., 2005). The measurement site, for the data collection includes two measurement containers for long-term PM and PM composition observation (Cyrys et al., 2006), is located at the University of Applied Sciences in Augsburg (48.3581 latitude; 10.9070 longitude), around $1 \mathrm{~km}$ south southeast of the city centre. The city centre is surrounded by compact residential areas and some industrial districts. Significant impact of traffic next to this site may be caused by the city circle motorway (approx. $120 \mathrm{~m}$ ) and the tram headquarter (approx. $50 \mathrm{~m}$ ). 


\subsection{AMS}

The Aerodyne AMS is a real-time measurement instrument for submicron non-refractory (NR) aerosol components, such as organics, sulphates, nitrates, and ammonium (Allan et al., 2004) with a $100 \%$ transmission efficiency in the AMS system for 70-500 $\mathrm{nm}$ sized particles and considerable transmission for particles in the 30-70 nm and $500 \mathrm{~nm}-2.5 \mu \mathrm{m}$ ranges (Jayne et al., 2000; Zhang et al., 2002). The AMS system and data analysis software have already been described in detail in several publications (DeCarlo et al., 2006; Canagaratna et al., 2007; Zhang et al., 2004). A high-resolution time-offlight aerosol mass spectrometer (HR-ToF-AMS, Aerodyne Research Inc., Billerica, MA,USA) was used in this campaign.

In this study the AMS was run alternatively between V(single stage reflectron) and $\mathrm{W}$-mode (double stage reflectron), with 2 min of measuring time for each mode. In this paper the $\mathrm{V}$-mode data are presented. The V-mode alternates between the mass spectrum (MS) mode for the total nonrefractory $\mathrm{PM}_{1}$ particle mass chemical composition (four 15-s intervals for chopper opened and closed every two minutes of measuring time) and the particle time-of-flight (PToF) mode for the particle size distribution (four 15-s intervals every two minutes of measuring time). The heater for the aerosol thermal desorption was run at $600^{\circ} \mathrm{C}$ and the tungsten filament for electron ionisation at an accelerating voltage of $70 \mathrm{eV}$, respectively. A collection efficiency (CE) of 0.5 was used for this instrument and applied to all AMS data. In a detailed discussion provided in the Sect. SI-1 of the Supplement it is shown that an acidity balance and nitrate dependence is given. However, a novel calculation of an alternated CE (Middlebrook et al., 2012) shows that the nitrate dependence does not affect the obtained results with a constant $\mathrm{CE}$ of 0.5. According to Bahreini et al. (2009) this CE could vary by around $20 \%$.

The servo position check and the lens alignment were made in the beginning of the campaign. Flow and size calibrations were performed before and after the campaign. Routine calibrations of the ionisation efficiency (IE), baseline, $\mathrm{m} / \mathrm{z}$ and single ion, as well as a gas phase correction that was carried out using a high efficiency particulate air (HEPA) filter in front of the sampling inlet, were performed every four to five days (Aiken et al., 2008).

The software package Igor Pro 6.12A (Wavemetrics, Lake Oswego, OR) was used as a basis for the standard AMS data analysis tools (SQUIRREL v1.49 and PIKA v.1.08, Sueper, 2010). The fragmentation table (Allan et al., 2004) was modified according to gas phase composition.

\subsection{PMF}

Positive matrix factorisation (PMF) is a bilinear unmixing model used to describe the measurements as a linear combination of factors. PMF was applied here to reconstruct the measured AMS organic mass spectra as a linear combination of factors characterized by a constant mass spectrum (factor profile) and a variable contribution over time (strength of the factor). Both the source profiles and the factors contributions are unknown. Strength and profile of the sources are constrained to be positive, representing physically meaningful positive concentrations and contributions in the model (Ulbrich et al., 2009; Lanz et al., 2007; Paatero and Tappert, 1994; Paatero, 1997). A detailed description of the PMF analysis is provided in Sect. SI-2 of the Supplement. The PMF analysis for the organics source apportionment was performed using the AMS PMF Toolkit version 2.03 developed by Ulbrich et al. (2009) together with the Igor Pro software. Organic concentrations and error matrix were obtained following the procedure described by Ulbrich et al. (2009). The final matrix was formed by 14285 time points and 268 massto-charge ratios from $m / z, 12$ to 300 . PMF was applied to the unit mass resolution AMS V-mode data recorded with a time resolution of $4 \mathrm{~min}$ due to the $2 \mathrm{~min}$ of measuring time for the $\mathrm{V}$ - and $\mathrm{W}$-mode.

\subsection{GC-MS}

$\mathrm{PM}_{1}$ filter samples were collected on quartz fibre filters with a one-hour time resolution from 15 to 19 February in order to determine the organic composition with in situ derivatisation thermal desorption gas chromatography time of flight mass spectrometry (IDTD-GC-ToFMS) (Orasche et al., 2011). Additionally, 17 daily $\mathrm{PM}_{2.5}$ samples were collected during the period of 1 to 24 February and analysed using the same method.

The $\mathrm{PM}_{1}$ samples were collected with a sequential low volume sampler (LVS3/SEQ 47/50, Leckel GmbH, Berlin, Germany) on quartz fiber filters (T293, Munktell, Grycksbo, Sweden) at a flow rate of $38.31 \mathrm{~min}^{-1}$. Sampling time was one hour, yielding a collected air volume of $2.3 \mathrm{~m}^{3}$. The $\mathrm{PM}_{2.5}$ samples were collected with a low volume sampler (Partisol-Plus Model 2025, Rupprecht \& Patashnick, NY, USA) using a flow rate of $16.71 \mathrm{~min}^{-1}$; within $24 \mathrm{~h}$ of sampling time airborne particulate matter of $24 \mathrm{~m}^{3}$ air was collected.

Prior to sampling, the quartz fiber filters were tempered for at least eight hours at $550^{\circ} \mathrm{C}$ to remove all organic matter. After sampling, the filters were cut into strips of $2 \times 13.5 \mathrm{~mm}$ $\left(27 \mathrm{~mm}^{2}\right)$ representing a volume of $0.047 \mathrm{~m}^{3}$ of ambient air for $\mathrm{PM}_{1}$ and $0.550 \mathrm{~m}^{3}$ for $\mathrm{PM}_{2.5}$. The filter strips were stored in glass containers at $-18^{\circ} \mathrm{C}$ until analysis by thermal desorption GC-MS. No significant difference between the analyte masses of $\mathrm{PM}_{1}$ (hourly filters) and $\mathrm{PM}_{2.5}$ (daily filters) were found

The principle of the analysis is to conduct an automatic in situ derivatisation with N-methyl-N-trimethylsilyltrifluoroacetamide (MSTFA) before thermal desorption, GC-MS separation and detection. As no manual extraction and derivatisation step is necessary before GC-MS analysis, 
this method is time saving (Orasche et al., 2011). It allows the analysis of non-polar and polar organic compounds in one measurement. Due to thermal desorption, low limits of quantification (LOQ) were reached (levoglucosan, mannosan, galactosan, and dodecanoic acid reached LOQs of $0.06,0.05,0.02$, and $0.06 \mathrm{ng}$, respectively).

The filter strips in a GC liner were spiked with an internal standard mixture of standard isotope labelled reference compounds, for instance, levoglucosan for quantification. For analysis an autosampler decaped the liners, added MSTFA directly onto the filter punches and put the GC liners directly into the injector (autosampler, Combi PAL, CTC Analytics AG, Zwingen, CH; LINEX-TD system, ATASGL, Veldhoven, NL). The injector increased its temperature from room temperature to $300^{\circ} \mathrm{C}$ and kept the temperature for $16 \mathrm{~min}$ (injection port: Optic III, ATAS-GL, Veldhoven, NL). During the high temperatures of thermal desorption, the carrier gas (helium) was enriched with gaseous MSTFA to ensure the ongoing silylation reaction. The derivatised and desorbed analytes were focused on a retention gap of deactivated fused silica with an oven temperature of $70^{\circ} \mathrm{C}$ (Retention gap: SGE, Ringwood, AUS; column: BPX5, SGE, Ringwood, AUS; and GC: Agilent 6890, Agilent, Palo Alto, CA, USA). After both procedures (thermal desorption and derivatisation reaction) were finished, no more MSTFA was added to the carrier gas and detection by GC-MS was started. Standard electron ionisation (EI) and ToF-MS equipment (Pegasus III, LECO Ltd., St. Joseph, MI, USA) was used for detection.

\subsection{Other instruments}

Another additional instrument used during this campaign was a scanning mobility particle sizer (SMPS) (TSI, model $3080,3022 \mathrm{~A}$ ). The SMPS was running continuously in parallel with the AMS to obtain particle number size distributions in the size range from 14 to $673 \mathrm{~nm}$. Furthermore, a twin differential mobility particle sizer (TDMPS) system combined with an aerodynamic particle sizer (APS, model 3321, TSI Inc., USA) was used to measure the particle size distribution in the range from $3 \mathrm{~nm}$ to $10 \mu \mathrm{m}$; the total used size range was from $50 \mathrm{~nm}$ to $1000 \mathrm{~nm}$. To convert the APS (aerodynamic) to TDMPS (mobility) diameter an effective density of $1.7 \mathrm{~g} \mathrm{~cm}^{-3}$ was assumed in the overlap range of 800 to $900 \mathrm{~nm}$ (Pitz et al., 2008). In addition, a condensation particle counter (CPC) (TSI, model 3025A) was used for total particle number concentration measurements.

An Aethalometer (Thermo Fisher Scientific Inc., USA, series 8100 ) was used to measure black carbon (BC). The $\mathrm{PM}_{2.5}$ mass concentration was measured using a tapered element oscillating microbalance (TEOM, model 1400ab, Thermo Fisher Scientific Inc., USA) equipped with a filter dynamics measurement system (FDMS model 8500b, Thermo Fisher Scientific Inc., USA). A sulfate particulate monitor (SPA, model 5020, Thermo Fisher Scientific Inc.,
USA) was used to measure $\mathrm{PM}_{2.5}$ particle-bound sulfate concentrations (cf. Fig. SI-3.2). Meteorological data including wind velocity and direction, temperature, relative humidity and global radiation were measured with an ultrasonic anemometer, resistance thermometer, capacitive humidity element and pyranometer, respectively (Adolf Thies GmbH \& Co. KG, Germany).

\section{Results and discussion}

\subsection{General}

During the campaign, the ambient temperature ranged from $-9.9^{\circ} \mathrm{C}$ to $14.4^{\circ} \mathrm{C}$ under typical seasonal weather conditions. $\mathrm{PM}_{2.5}$ mass concentration ranged from $1.17 \mu \mathrm{g} \mathrm{m}^{-3}$ to $110.7 \mu \mathrm{g} \mathrm{m}^{-3}$. Beside the weather condition and $\mathrm{PM}_{2.5}$ mass concentration, Fig. 1 shows the hourly mean time series of the main submicron aerosol components from the AMS data, such as organic matter, nitrate, sulphate, ammonium and the $\mathrm{PM}_{2.5}$ BC Aethalometer data during the whole campaign. A high variation in particulate matter (PM) concentration and composition could be observed with higher $\mathrm{PM}_{2.5}$ concentrations during cold and snowy periods, while lower concentrations were observed during warm and rainy periods. In a phase of high PM concentrations (above $20 \mu \mathrm{g} \mathrm{m}^{-3}$ ) from 5 to 20 February (average temperature of $-2.4{ }^{\circ} \mathrm{C}$ ) the low wind speeds (WS) (on average $1.2 \mathrm{~m} \mathrm{~s}^{-1}$ ) are accompanied with little vertical air exchange and an increase of secondary inorganic aerosol. The phase of low PM concentrations (below $8 \mu \mathrm{g} \mathrm{m}^{-3}$ ), e.g. from 25 February to 2 March (average temperature: $6.4^{\circ} \mathrm{C}$ ), has a higher average WS of $2.1 \mathrm{~m} \mathrm{~s}^{-1}$ and in phases with extremely low PM (below $3 \mu \mathrm{g} \mathrm{m}^{-3}$ ) a WS of up to $6 \mathrm{~m} \mathrm{~s}^{-1}$. Normally, the visually observed snow falls had no impact on the PM concentration as measured by AMS, but two special events could be observed with abrupt increases in PM in the morning hours of 11 February and 3 March 2010, concurrent with humid snow fall events.

\subsection{Source apportionment results}

The PMF analysis of the AMS data provides a three-factor solution for the source apportionment of the organic matter. This three-factor solution was chosen to describe the major sources of organic matter due to the structure of their mass spectra, time series and high correlation coefficient by comparing the factor time series with results from other measurements of source-related species. The largest contribution to the total OM mass is represented mostly by the oxygenated fraction (oxygenated organic aerosol, OOA) typically interpreted to be mainly of secondary origin. The second factor is hydrocarbon-like and attributed to freshly emitted organic aerosol (HOA) from fossil fuel combustion, and the third factor is identified as wood combustion organic aerosol (WCOA). Source interpretations are based on the MS comparison of these estimated PMF 

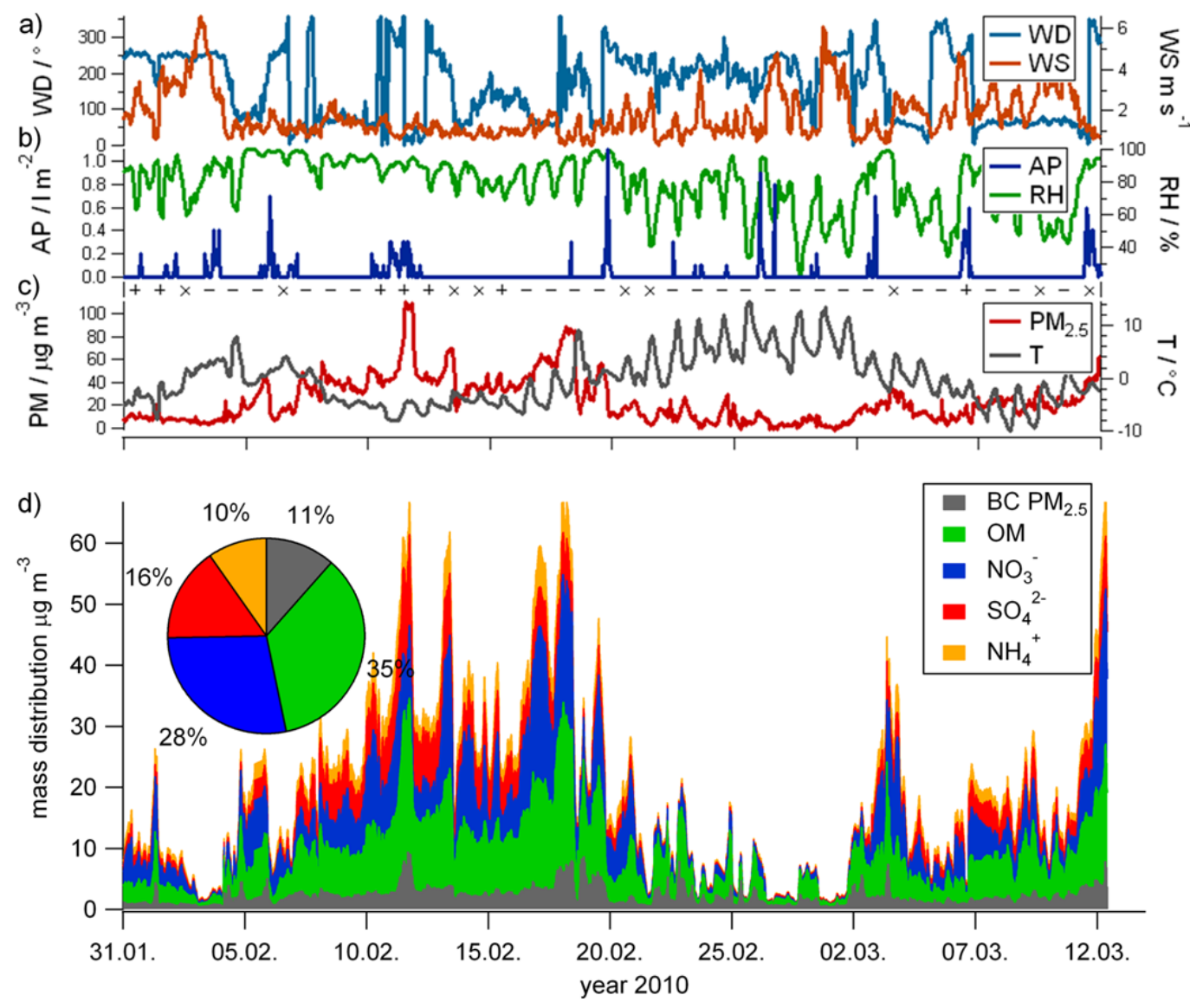

Fig. 1. Time series of meteorological and PM data: (a) wind direction (WD/grey blue) and wind speed (WS/brown); (b) atmospheric precipitation (AP/dark blue), relative humidity (RH/green) and daily observation of snow fall events $(+=$ snow fall, $-=$ no snow fall and $\times=$ light snow fall); (c) particulate matter $\left(\mathrm{PM}_{2.5} / \mathrm{red}\right)$ and temperature (T/grey) and (d) hourly mean time series of submicron aerosol components

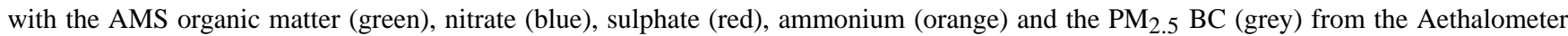
data. An individual overview of components is given in the supplemental material (Fig. SI-3.1).

factors (Fig. 2a) with representative source MS from previous studies (http:cires.colorado.edu/jimenez-group/AMSsd, July 2011). A high similarity is obtained with the MS factor from a PMF solution during a winter measurement campaign in Grenoble (Favez et al., 2010). The European Alp city of Grenoble has a population size similar to that of Augsburg. The comparison of the Augsburg and Grenoble factors for OOA, HOA and WCOA over 246 data points is in good agreement with the correlation coefficient of $R^{2}=0.47,0.84$ and 0.66 , respectively. In addition to the three-factor PMF solution, a four-factor solution was also evaluated. In the four-factor PMF analysis the new factor shows parts from the OOA and WCOA components. However, this four-factor PMF solution, in comparison to the three-factor solution, provides inferior correlations with the measured data set. For instance, HOA and the signal of $m / z 57$ correlate with just a $R^{2}$ of 0.43 . Additional in this four-factor solution HOA shows a high correlation with $m / z, 44\left(R^{2}=0.93\right)$ in contrast to OOA $\left(R^{2}=0.43\right)$. More information about the four-factor
PMF solution is provided in Sect SI-2.2 and in Table SI-1 of the Supplement. A possible food cooking factor has not been found in PMF analysis. Additionally, the AMS does not provide a high ratio of the $m / z 55$ and 57, which would be a robust marker for food cooking (Mohr et al., 2012).

Matrix rotation was explored in the 3-factor solution using the "FPEAK" parameter of the PMF. The mass spectra and time series variations in the FPEAK range from -1 up to +1 with a step of 0.1 were analysed and are summarised in Fig. SI-2.2. The $Q / Q_{\text {expected }}$ ratio (Sect. SI-2.2 of the Supplement; Paatero, 1997) is constant for various FPEAKs. FPEAK equal to 0.2 showed good correlations between reference mass spectra (Favez et al., 2010), marker ions (Fig. 3) and source-related species data (Fig. 4). PMF solution with negative FPEAK values provide weaker correlations of calculated factor with temporal variation of the source-related tracer species, while the PMF solution of positive FPEAK values showed similar correlations with tracer species as the FPEAK $=0$. However, the FPEAK 0 solution 
a)
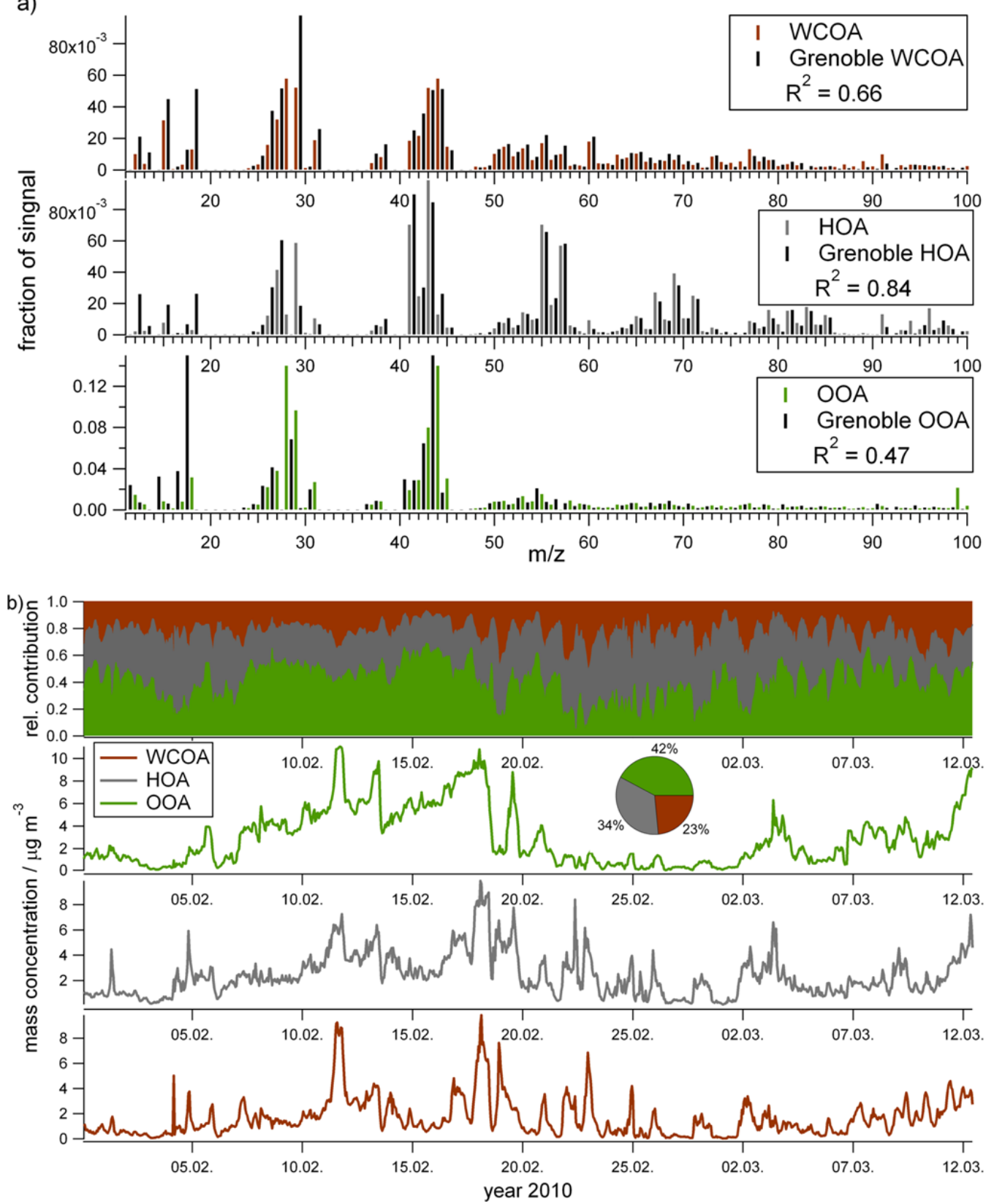

Fig. 2. AMS PMF results of the period from 31 January to 12 March, with FPEAK $=0.2$. (a) Campaign calculated mass spectra of the PMF factors compared with reference mass spectra from Grenoble, January 2009 (Favez et al., 2010) and (b) time series of the hourly mean PMF factors and their averaged and relatively contribution to total organic matter.

is between the negative and positive FPEAK and shows a step in the factor contribution. Due to this, the FPEAK 0.2 is chosen for the subsequent analysis as a more stable PMF solution. Some variation of the factor mass spectra in FPEAK dependency over all FPEAKs is observed in the mass spectra from WCOA and OOA, whereas only the time series of the HOA and OOA are changed (Figs. SI-2.2 and SI-2.3).
The average relative contribution of the OOA, HOA and WCOA factors are $42 \%$ (range 2-69\%), 34\% (range $19-78 \%$ ) and $23 \%$ (range 6-62\%), respectively. The contribution of OOA to total organic matter is approximately $55 \%$ in the periods of high PM concentrations and approximately $25 \%$ in the warm and humid periods. As it is indicated by the four-factor PMF solution, some parts of the OOA could originate from WC. For example Heringa et al. (2011) showed 


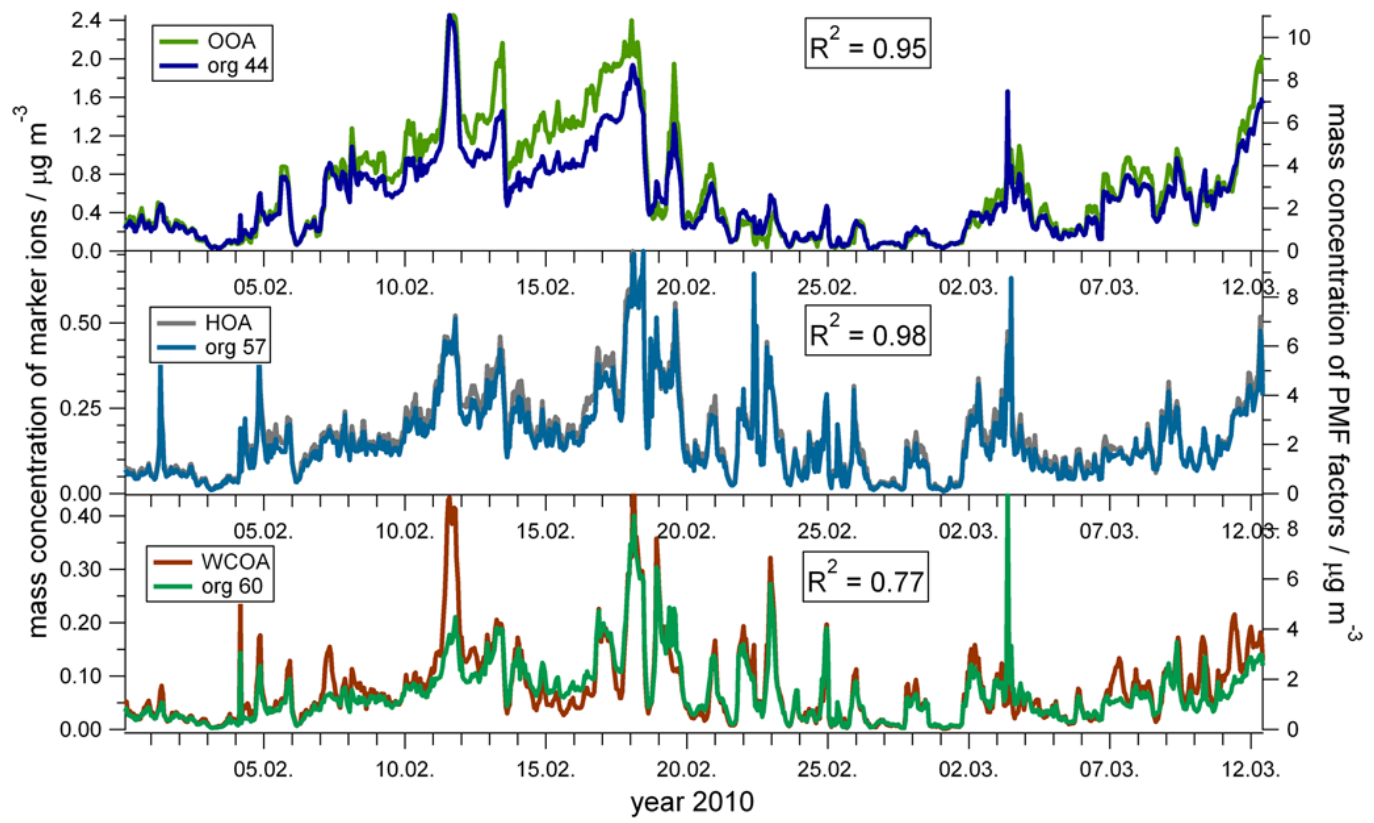

Fig. 3. Hourly averaged time series of WCOA (brown), HOA (grey) and OOA (green) PMF factors mass concentrations on the right axis correlated with hourly averaged mass concentrations of the marker ions $m / z 60$ (turquoise), $m / z 57$ (blue) and $m / z 44$ (light blue) from the AMS on the left axis.

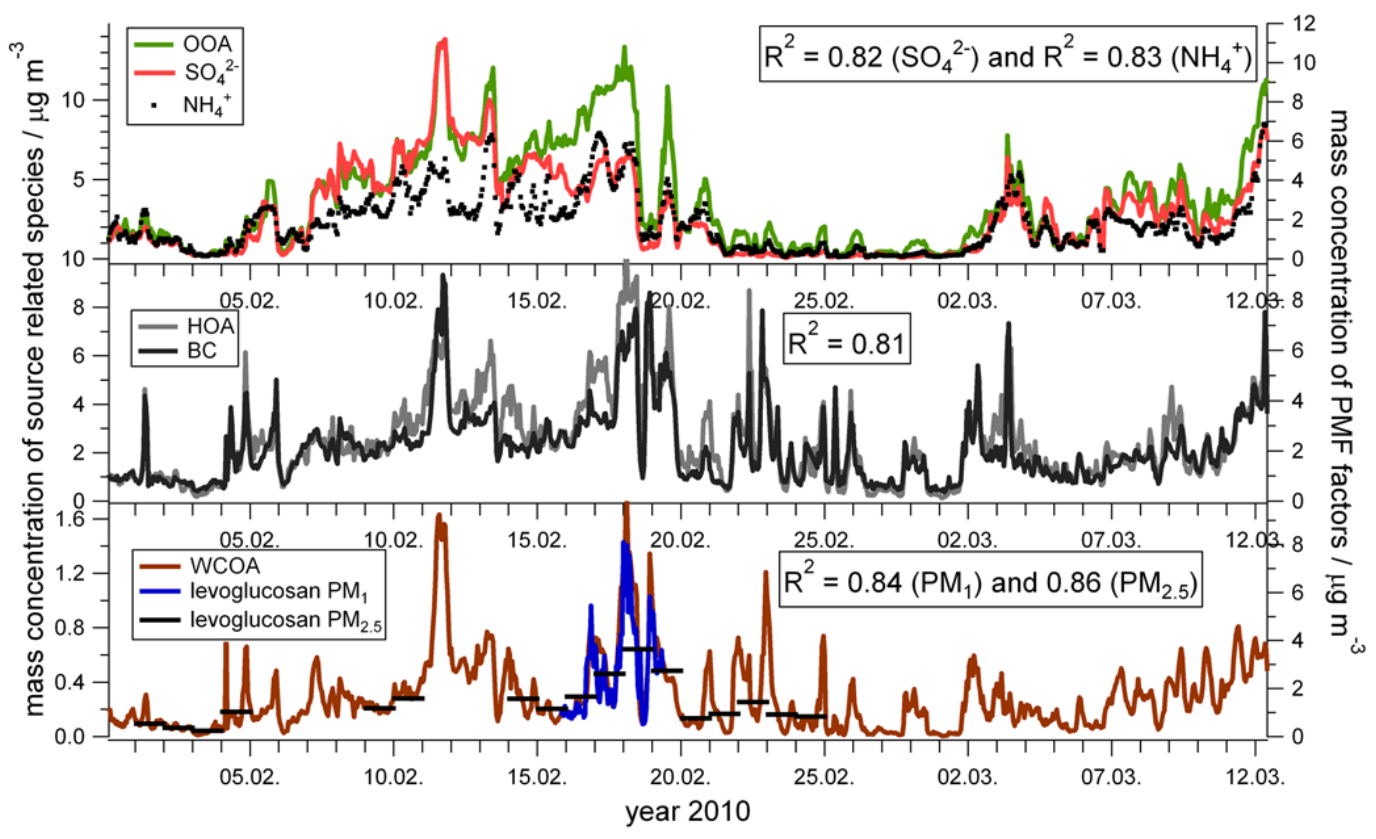

Fig. 4. Hourly averaged time series of OOA (green), HOA (grey) and WCOA (brown) PMF factors correlate with AMS sulphate (red), ammonium (black dots), $\mathrm{PM}_{2.5}$ Aethalometer BC (black line) and hourly $\mathrm{PM}_{1}$ (blue) and daily $\mathrm{PM}_{2.5}$ (black line) levoglucosan GC-MS data.

that WC gas phase compounds (Hawthorne et al., 1989) could increase the SOA and the OOA production, respectively. During the warm and humid periods, HOA has a maximum contribution of around $60 \%$ to the total organic matter.
Hence, freshly emitted aerosol has the largest influence in warm and rainy periods. The high content of HOA, compared to other studies, is probably due to the surroundings of the measurement site with the city circle motorway and some 
main routes of the city being close by. The daily averaged contribution of WCOA, with about $20 \%$ (range 10-30\%) to total OM mass, is quite constant during the whole campaign and shows no inverse correlation with the daily averaged temperatures. Nevertheless, diurnal variation of peak values can be observed, especially in the evening and at night, when regional domestic heating starts.

To support the interpretation of the PMF factors the time series of the marker ions $m / z$ 44, 57 and 60 (Zhang et al., 2005; Aiken et al., 2009; Alfarra et al., 2007) and the source associated species $\left(\mathrm{SO}_{4}^{2-}, \mathrm{NH}_{4}^{+}, \mathrm{BC}\right.$ and levoglucosan) were correlated with the factors time series and showed a correlation coefficient of $R^{2}>0.77$ (Figs. 3 and 4). The WCOA factor correlates well with the WC marker ion of $\mathrm{m} / z 60$ $\left(R^{2}=0.77\right.$, Fig. 3$)$. The correlation of OOA with OOA marker ion $m / z 44$ is even higher $\left(R^{2}=0.95\right)$. The main differences between the temporal variations of OOA and $m / z$ 44 data are observed during the times when the HOA concentration is notably high. The HOA is highly correlated with the primary marker ion $m / z 57\left(R^{2}=0.97\right)$. Chirico et al. (2010) showed that aged diesel emissions contain high fractions of the oxygenated fragment of the $m / z 57$ signal which is produced by oxidative processes. However, the high correlation of $m / z 57$ and HOA found in our study is not surprising, because both main fragments which contribute to $m / z$ 57, the oxygenated fragment $\left(\mathrm{C}_{3} \mathrm{H}_{5} \mathrm{O}^{+}\right)$and the nonoxygenated fragment $\left(\mathrm{C}_{4} \mathrm{H}_{9}^{+}\right)$, show a high correlation with HOA $\left(R^{2}=0.85\right.$ and 0.88 , respectively). Additionally, the latter fragment contributes the most to the $m / z 57$ signal, which is approximately $47 \%$. It can also be seen that only the oxygenated fragment $\left(\mathrm{C}_{3} \mathrm{H}_{5} \mathrm{O}^{+}\right)$provides good correlations $\left(R^{2}=0.80\right.$ and 0.72$)$ with WCOA and OOA, respectively.

A high correlation is found as well between the concentrations of the source-related species and the results from the PMF analysis (Fig. 4). The time series of OOA and the three main inorganic components sulphate, nitrate and ammonium used as markers for oxygenated aerosol result in correlations of $R^{2}=0.82,0.68$ and 0.83 , respectively. Additionally, the AMS sulphate data show a good correlation $\left(R^{2}=0.85\right)$ with data from the sulphate monitor (Fig. SI3.2). Primary aerosol mass HOA correlates well $\left(R^{2}=0.81\right)$ with Aethalometer $\mathrm{BC}$ data. $\mathrm{BC}$ is mainly attributed to traffic and other combustion emissions like wood combustion (Szidat et al., 2007). The WCOA factor is in good correlation $\left(R^{2}=0.84\right)$ with the levoglucosan measurements from the hourly $\mathrm{PM}_{1}$ GC-MS filters and as well $\left(R^{2}=0.86\right)$ with the levoglucosan measurements from the daily $\mathrm{PM}_{2.5}$ GC-MS filters.

\subsection{Wood combustion results}

In Fig. 5, the diurnal variation of AMS levoglucosan equivalent concentration data is displayed as hourly averages of the whole campaign. The AMS levoglucosan equivalent concentration was calculated from the organic fraction of $\mathrm{m} / \mathrm{z}, 60$

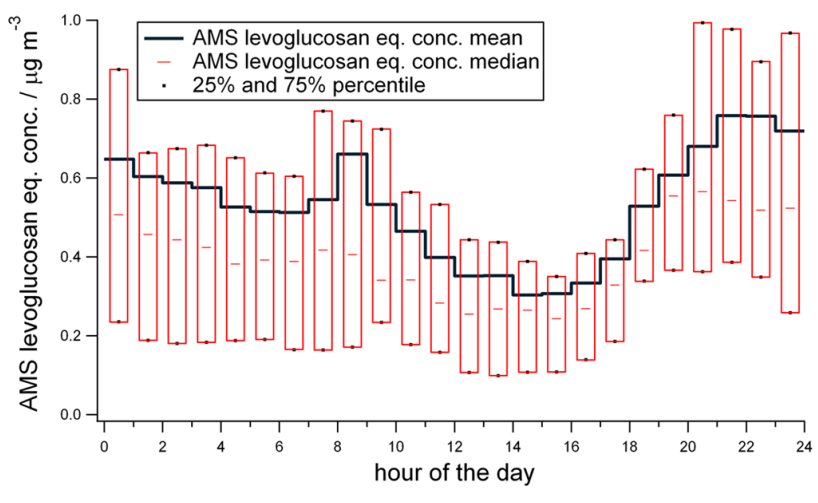

Fig. 5. Diurnal variation of AMS levoglucosan equivalent concentration displayed as a box plot during the whole campaign calculated from 14285 data points.

by subtracting the organic background and multiplied by an instrument-specific levoglucosan standard factor (11.24 for our instrument) consisting of the ratio of $\mathrm{m} / z 60$ to total organic signal from a levoglucosan standard mass spectrum (Aiken et al., 2009). The organic background has been found to be approximately $0.3 \%$ of the total organic aerosol signal in several field campaigns, in periods and areas with absence of WC impacts (DeCarlo et al., 2008; Docherty et al., 2008). The calculation of the AMS levoglucosan equivalent concentration from the signal of $m / z, 60$ is discussed in detail in Sect. 3.4. The WC contribution strongly increases during the evening period from 06:00 p.m. to 09:00 p.m. after the end of regular working time and rush hour, i.e. when people arrive at home and start domestic heating by wood combustion. During the night, the concentration remains approximately constant with a small decrease indicating low emissions and stable atmospheric conditions with low wind speed and low mixing layer height. In contrast, a minor increase of levoglucosan is observed in the morning from 07:00 a.m. to 10:00 a.m. with a maximum from 08:00 a.m. to 09:00 a.m. Previous studies by Sandradewi et al. (2008b) have also shown a maximum for WC in the evening and night period, and Krecl et al. (2008) have observed the evening increase for traffic and WC related BC. The daily minimum in the afternoon was probably produced by a decreased WC activity together with an increase in mixing layer height during the day. The GC-MS levoglucosan daily variation of $\mathrm{PM}_{1}$ filters shows a similar profile, except for the high morning peak and some spikes due to the low number of GC-MS data points (Fig. SI-3.3). The AMS levoglucosan equivalent concentration to $\mathrm{OM}$ mass ratio indicates a longer emission period on the weekend from the morning hours until noon compared to working days, which is expected, considering the normal weekend activities where people are more likely to spend the morning at home.

The PMF factor diurnal variations are shown in Fig. 6. Similar to the AMS levoglucosan equivalent concentration 


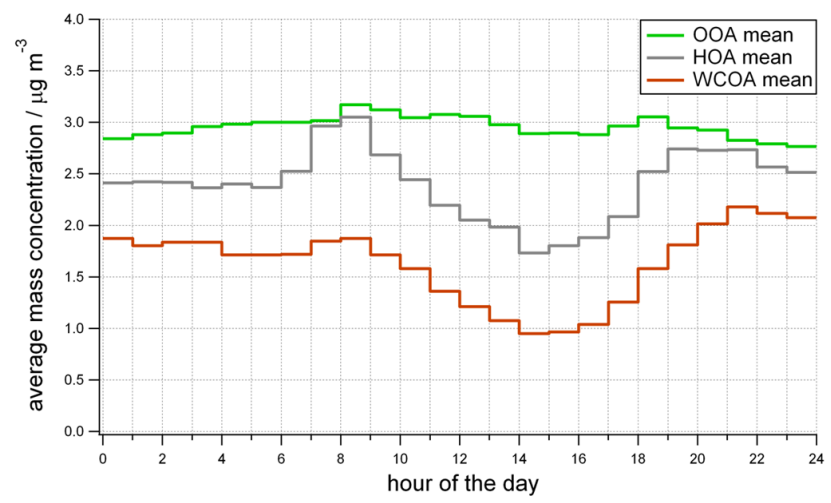

Fig. 6. Diurnal variation of the AMS PMF factor OOA (green), HOA (grey) and WCOA (brown) during the whole measurement period of the campaign.

variation, the WCOA variation shows a strong increase in the evening hours from 04:00 p.m. to 09:00 p.m. and a maximum followed by a constant level at night from 09:00 p.m. to 01:00 a.m. The WCOA fraction contributes with approximately $27 \%$ to the total OM mass in the latter period. The morning peak is smaller compared to the AMS levoglucosan equivalent concentration. Except for the less pronounced morning peak, the WCOA diurnal variation matches well with the GC-MS levoglucosan variation (Fig. SI-3.3). The HOA morning and evening maxima were obtained during the traffic rush hours. The HOA variation additionally shows a small increase around noon and a decrease after the rush hours in the night. The OOA is the largest fraction of the organic matter at any time and shows no distinctive maximum like the variations of HOA and WC.

For a discussion of the aerosol chemistry and the wood combustion impact on the aerosol the view of ratios are often considered, e.g. OM mass to organic carbon (OC) ratio. However, these ratios, as discussed below for the different levoglucosan to $\mathrm{OC}$ ratios and ranges, are strongly linked to external circumstances and influences.

The OM to OC ratio calculated from the AMS high resolution data of this study amounts to an average of 1.7. Favez et al. (2010) found a similar ratio of 1.78 in Grenoble (French Alps) in wintertime. The OM to OC ratios for hydrocarbonlike and oxygenated organic aerosols have previously been found to be in the range of 1.2 to 1.4 and 1.8 to 2.4 , respectively (e.g. Turpin and Lim, 2001; Aiken et al., 2008).

The following ratios from this study represent the estimated slope of the linear orthogonal regression from data comparisons over 87 data points. The $\mathrm{PM}_{1}$ levoglucosan analyzed by the GC-MS represents $3.4 \%$ of the total OM mass and $14.3 \%$ of the PMF WCOA mass in this study. The GC-MS levoglucosan to WCOA ratio compared to other studies is relatively high. For example, Lanz et al. (2008) found a ratio of $8 \%$ at an urban background site in Zurich during January 2006. In our study the levoglucosan to OC ratio amounts to 0.06 (ratio of the quotient ranged from 0.02-0.16). The OC concentrations were calculated from the OM to OC ratio and OM of the AMS high resolution data. The diurnal variation of levoglucosan to $\mathrm{OC}$ ratio (range 0.03-0.9) provides a similar variation as the GC-MS levoglucosan variation (Fig. SI-3.3), only with stronger increases and decreases. Several studies (Puxbaum et al., 2007; Sullivan et al., 2008) pointed out that the fuel type used has a strong impact on this ratio (for instance, hardwood or softwood and even the wood species in those groups themselves). Additionally, the burning conditions and the use of wood or pellet boilers have an impact on this ratio (Johansson et al., 2004; Schmidl et al., 2008; Hedberg et al., 2006). Considering the range of variability of the levoglucosan to $\mathrm{OC}$ ratio due to these influences on the ratio, Table 1 shows that the observed ratio in this study is within a similar range as compared to the above-mentioned emission and ambient studies. The Augsburg ratio is similar to the results obtained in the French Alpine city of Grenoble (around 157000 inhabitants), and higher than results obtained in Beijing (Zhang et al., 2008), where a major OC contribution may be related to traffic.

\subsection{Correlation of AMS and one-hour $\mathrm{PM}_{1}$ filter WC results}

The wood combustion measurement data of the AMS are compared with hourly $\mathrm{PM}_{1}$ filter GC-MS measurements of levoglucosan and additional anhydrosugars in this section. The signal of $m / z 60$ or rather the ion $\mathrm{C}_{2} \mathrm{H}_{4} \mathrm{O}_{2}^{+}$is the main marker of WCOA and is mainly formed from levoglucosan $\left(\mathrm{C}_{6} \mathrm{H}_{10} \mathrm{O}_{5}\right)$ (Alfarra et al., 2007; Aiken et al., 2009). During this Augsburg campaign the main contributor to the signal of $m / z 60$ in the ambient aerosol is the ion fragment $\mathrm{C}_{2} \mathrm{H}_{4} \mathrm{O}_{2}^{+}$ (93\% of $\mathrm{m} / \mathrm{z} 60)$. This is in agreement with results from other campaigns (Aiken et al., 2009; Mohr et al., 2009; Lee et al., 2010).

The time series of levoglucosan from GC-MS and AMS measurements show a good correlation with $R^{2}=0.84$ (Fig. 7b) and the daily variations of the GC-MS data are well reflected by the AMS data (Fig. 7a). The AMS levoglucosan equivalent concentration is about 2.8 times higher than the levoglucosan concentration from the GC-MS measurements. Aiken et al. (2009) also found a higher factor of 3.2, thus an overestimation (offset) of the AMS levoglucosan equivalent concentration. The offset found in our study can be explained by other compounds that contribute to $m / z 60$ and raise the AMS levoglucosan equivalent concentration results. The other anhydrosugars like the WC compounds mannosan and galactosan contribute to $m / z 60$ as well; the GC-MS data additionally include these compounds to the levoglucosan concentration (Fig. 7a). This addition increases the levoglucosan concentration by approximately $10 \%$. The ratio of levoglucosan and mannosan is 11.4 , which is close to the typical ratios for beech wood (14.8) and oak wood (14.2) combustion 
Table 1. Literature data of levoglucosan to OC ratios from emission and ambient studies. The OC content was mainly analysed by using a thermal/optical transmission (TOT) method (Birch and Cary, 1996) with a Sunset Lab analyzer and is referred to OC from WC in the emission studies and total OC in the ambient studies. The OC content in this study is calculated from the OM mass of AMS data and the high resolution data (OM to OC ratio).

\begin{tabular}{|c|c|c|c|}
\hline source place & fuel type & levoglucosan / OC & reference \\
\hline fire place & $\begin{array}{l}\text { hardwood } \\
\text { softwood }\end{array}$ & $\begin{array}{l}0.14 \\
0.04\end{array}$ & Fine et al. (2002) \\
\hline fire place & $\begin{array}{l}\text { hardwood } \\
\text { softwood }\end{array}$ & $\begin{array}{l}0.076 \text { to } 0.334 \\
0.010 \text { to } 0.271\end{array}$ & Fine et al. (2004a) \\
\hline wood stove & $\begin{array}{l}\text { beech } \\
\text { spruce }\end{array}$ & $\begin{array}{l}0.08 \\
0.21\end{array}$ & Puxbaum et al. (2007) \\
\hline stack burn & oak & 0.06 & Sullivan et al. (2008) \\
\hline $\begin{array}{l}\text { Beijing, China } \\
\text { (July } 2002 \text { to July } 2003 ; \\
\text { monthly mean) }\end{array}$ & ambient & 0.012 to 0.035 & Zhang et al. (2008) \\
\hline $\begin{array}{l}\text { Grenoble, France } \\
\text { (14 to } 29 \text { January } 2009 ; \\
\text { median) }\end{array}$ & ambient & 0.09 & Favez et al. (2010) \\
\hline $\begin{array}{l}\text { Augsburg, Germany } \\
\text { (13 February to } 12 \text { March } \\
\text { 2008; orthogonal fit) }\end{array}$ & ambient & 0.10 & unpublished study \\
\hline $\begin{array}{l}\text { Augsburg, Germany } \\
\text { (15 to } 19 \text { February } 2011 \text {; } \\
\text { orthogonal fit) }\end{array}$ & ambient & 0.06 & this study \\
\hline
\end{tabular}

(Schmidl et al., 2008). Thus the AMS equivalent levoglucosan offset is still too high and cannot be explained by the inclusion of these anhydrosugars. However, Lee et al. (2010) named the AMS levoglucosan equivalent concentration as AMS anhydrosugar equivalent concentration, which may be a more convenient expression and will be used in the following discussions. There must be other compounds co-emitted with the anhydrosugars sustaining the high correlation $R^{2}=$ 0.84 . Various carboxylic acids are emitted from wood combustion (e.g. Fine et al., 2004b). These acids also produce the fragment due to a McLafferty rearrangement over a six membered transition state after EI (McLafferty, 1959) and thus contribute to the $m / z 60$ signal from wood combustion. Additionally, one may speculate that cellulose from incomplete combustion is pyrolysed by the AMS heater, forming levoglucosan and therefore contributing to the $m / z$, 60 signal (Lee et al., 2010). Another study (Mohr et al., 2009) reported a contribution to $\mathrm{m} / \mathrm{z} 60$ from food cooking aerosols. For this and for other sources additional important contributors to $m / z 60$ could be long-chain carboxylic acids, e.g. fatty acids like dodecanoic acid and octadecanoic acid, as shown above. Long-chain carboxylic acids with chain-lengths from $\mathrm{C}_{12}-\mathrm{C}_{20}$ play an important role for ambient aerosols as shown in several studies, cited in Mirivel et al. (2009). Our GC analyses provide qualitative and quantitative information on these acids. Dodecanoic acid, for example, shows high concentrations with an average of $60 \mathrm{ng} \mathrm{m}^{-3}$. It is possible that not all of these compounds are completely covered by the subtracted background $(0.3 \%$ of the total OM). A detailed view at the $m / z 60$ signal with the PMF factor of OOA (Fig. 2a) shows that the contribution of the secondary aerosol source factor OOA to the $m / z 60$ signal matches with the amount of subtracted organic background $(0.3 \%$ of the total OM) from the $m / z 60$ signal of the calculation of the AMS levoglucosan equivalent concentration. Both show a correlation of their time series of $R^{2}=0.83$. The OOA contribution to the $m / z 60$ signal represents $70 \%$ of the organic background during the whole campaign, except in low PM concentration periods. Then the OOA roughly provides a value that is a factor of two lower than the organic background. Note that the PMF analysis is a statistical calculation with variability opportunities; this detailed view at signal of $\mathrm{m} / \mathrm{z}$ 60 can only show that the subtracted organic background is in a reasonable range for the SOA. Additionally, this discussion shows that beside levoglucosan as a main contributor other compounds are contributing to the signal of $m / z 60$, too. These compounds could come from WC (e.g. mannosan, galactosan or cellulose) or could be long-chain carboxylic acids (e.g. from food cooking, WC or SOA), which are not completely covered by the subtracted background. 

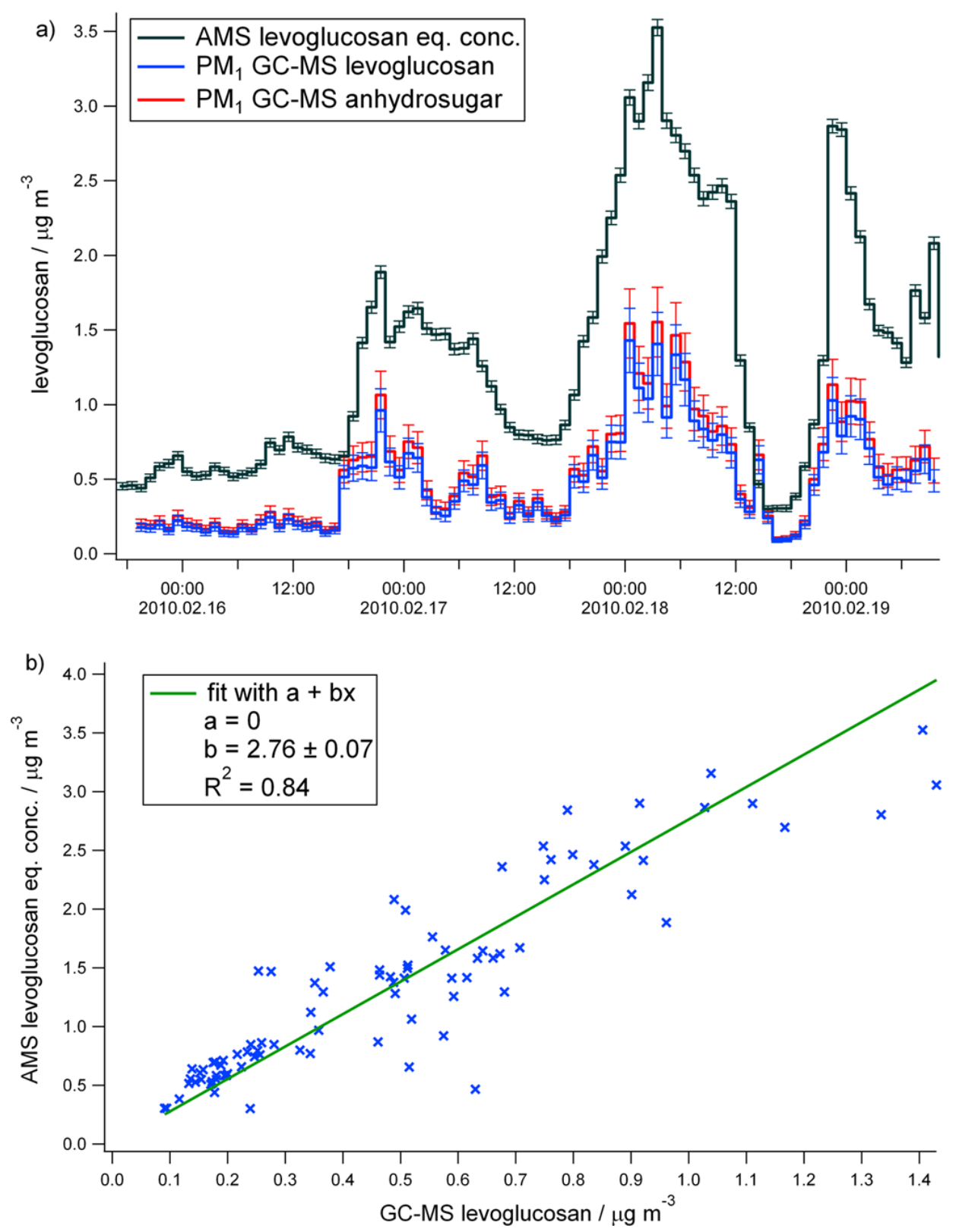

Fig. 7. (a) Time series of hourly mean AMS levoglucosan equivalent concentration (dark blue), PM 1 GC-MS levoglucosan (light blue) and sum of anhydrosugar (red) results in the week of 15 to 19 February. The error bars of the GC-MS data reflect the $15 \%$ uncertainty associated with the method; the AMS levoglucosan equivalent concentration error bars were calculated with the SQUIRREL software for each species. (b) Scatter plot of hourly mean AMS levoglucosan equivalent concentration versus PM $_{1}$ GC-MS levoglucosan. Regression values are calculated with the orthogonal distance regression.

Similar to the diurnal variations, the time series of the PMF WCOA factor and the $\mathrm{PM}_{1}$ GC-MS levoglucosan data show a high correlation of $R^{2}=0.84$ during the $\mathrm{PM}_{1}$ filter sampling period (Fig. 8). The main disagreement occurs at the same time as for the AMS anhydrosugar equivalent concentration in the period from 03:00 a.m. to 06:00 a.m. on 17 February. Both the AMS anhydrosugar equivalent concentration and the WCOA variations correlate with $R^{2}=0.71$ during the whole campaign period and with $R^{2}=0.97$ over the $\mathrm{PM}_{1}$ filter period.

The slope between the WCOA and GC-MS levoglucosan is around 7 and is relatively low in comparison to other studies. A study of Lanz et al. (2008) estimated in Zurich in January 2006 a WCOA to GC-MS levoglucosan ratio of 12.5. Aiken et al. (2009) found a ratio of 16.3 in Mexico City; the WCOA derives here mainly from wild fires and 

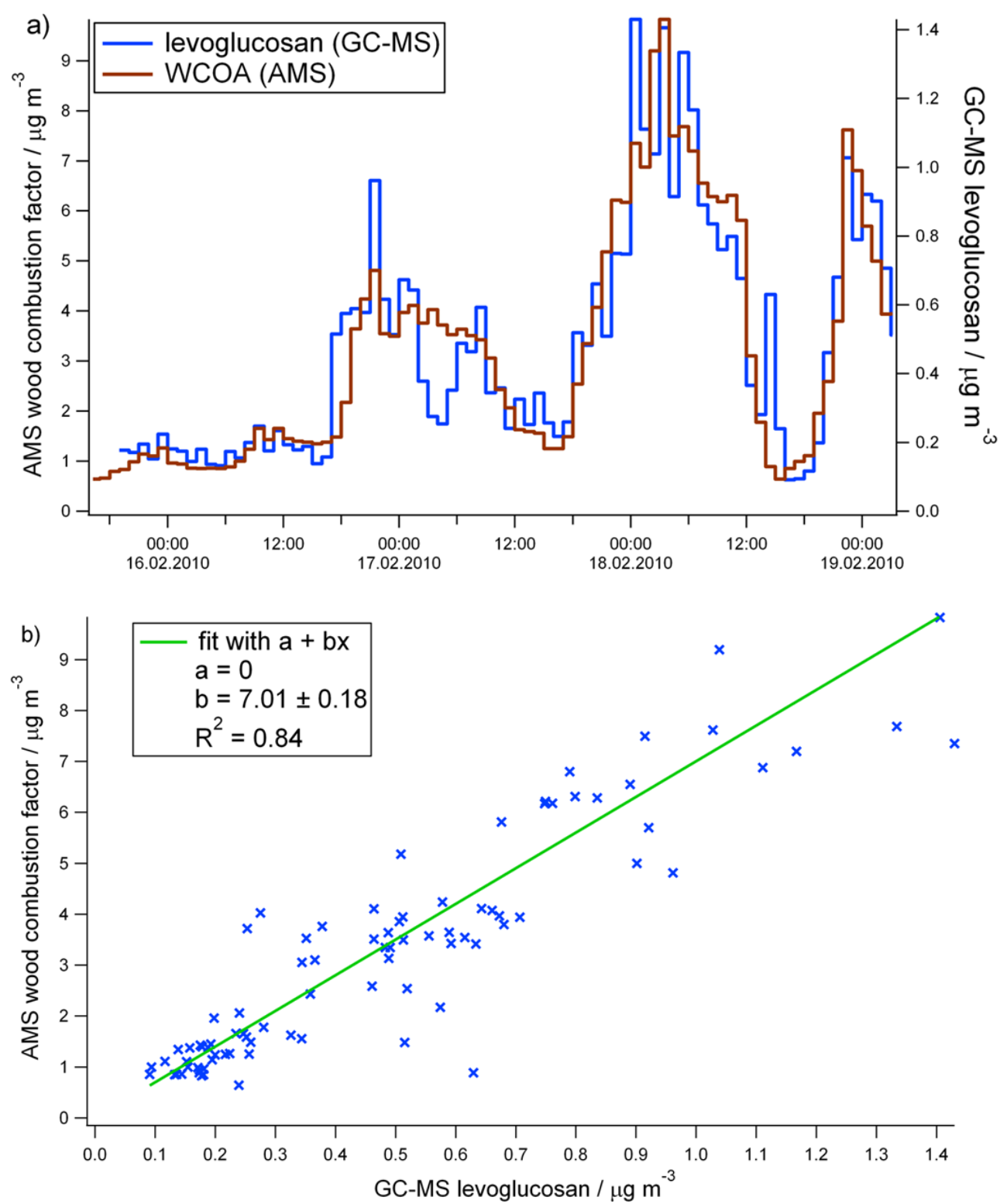

Fig. 8. (a) Time series of the hourly mean PMF WCOA factor (brown) and the hourly $\mathrm{PM}_{1}$ GC-MS levoglucosan data (blue) during the week of 15 to 19 February. (b) Scatter plot of hourly mean PMF WCOA factor versus PM $_{1}$ GC-MS levoglucosan. Regression values are calculated with the orthogonal distance regression.

biomass burning. Similar to the levoglucosan to OC ratios as shown above in Sect. 3.3, the WCOA to levoglucosan ratio depends on the fuel type and the combustion conditions (e.g. Puxbaum et al., 2007; Hedberg et al., 2006).

Both estimations, the WCOA and the AMS anhydrosugar equivalent concentration, allow to observe variation with time of WC emission, with a good gradient correlation of $R^{2}=0.84$. However, the WCOA is more suitable for the quantitative observation (estimated magnitude) of WC emission than the AMS anhydrosugar equivalent concentration, due to the measured offset by the comparison with the GC-MS levoglucosan.

\section{Conclusions}

The present study gives an overview of the Augsburg winter campaign 2010 including a detailed view of the WC results obtained by two different mass spectrometry methods. The first comparison of hourly $\mathrm{PM}_{1}$ filter GC-MS measurements with AMS data under ambient conditions represents the particular novelty of this study. Additionally, it includes a detailed view of the dynamic changes of the aerosol composition over the day, which confirms that WC has an important influence on aerosol composition. 
The main submicron aerosol fractions obtained by the AMS are organic matter with $35 \%$ and nitrate with $28 \%$ of the total mass measured by the AMS and Aethalometer in Augsburg during winter. This is typical for winter in Central Europe (Lanz et al., 2010). The organic aerosol fraction is based on three main sources found by PMF analysis, with the secondary process associated OOA as the largest contributor with $42 \%$ and WCOA with $23 \%$ as one of the main contributors. The influence of WC is particularly important for the aerosol composition with $28 \%$ in the evening and the night hours, while the primary HOA emission factor is of higher concern during the morning rush hours. Here HOA contribution increases to $38 \%$. The levoglucosan to $\mathrm{OC}$ ratio on average amounts to 0.06 in this study and is comparable to other ambient WC observations.

The comparison of GC-MS levoglucosan measurements from the highly time resolved $\mathrm{PM}_{1}$ filters with AMS data shows that either AMS WCOA or alternatively AMS levoglucosan equivalent concentration analysis have a high gradient correlation $\left(R^{2}=0.84\right)$ and are therefore suitable for the observation of WC emission variation. Similar to Aiken et al. (2009), we found that the AMS levoglucosan equivalent concentration (AMS anhydrosugar equivalent concentration; Lee et al., 2010) is higher than the GC-MS levoglucosan concentration. Therefore, we argue that not only levoglucosan contributes to the WC marker ion at $m / z 60$ (HR fragment ion $\mathrm{C}_{2} \mathrm{H}_{4} \mathrm{O}_{2}^{+}$). Additionally, other components from WC emissions, like mannosan or galactosan or, as shown in other studies, cellulose (Lee et al., 2010), could contribute to the signal of $m / z$ 60. Different analyses of additional GCMS data and PMF results reveal that long-chain carboxylic acids could additionally increase the $m / z 60$ signal and that the subtracted organic background is comparable to the OOA fraction of the $m / z 60$ signal. Therefore a quantitative estimation of the AMS anhydrosugar equivalent concentration is difficult. The analysis of the diurnal variation of the PMF factors appears to be important for the interpretation of the organic sources and their estimated magnitude, especially for WC. The PMF WCOA diurnal variation presents a similar profile as the hourly $\mathrm{PM}_{1}$ GC-MS levoglucosan results.

\section{Supplementary material related to this article is available online at: http://www.atmos-chem-phys.net/12/ 6113/2012/acp-12-6113-2012-supplement.pdf.}

Acknowledgements. We like to thank Ph. D. Günther Bahnweg, (University of Michigan), for carefully reading the English version of the manuscript. This project was supported by the Swiss IMBALANCE project (IMpact of Biomass burning AerosoL on Air quality aNd ClimatE).

Edited by: B. Ervens

\section{References}

Aiken, A. C., DeCarlo, P. F., Kroll, J. H., Worsnop, D. R., Huffman, J. A., Docherty, K., Ulbrich, I. M., Mohr, C., Kimmel, J. R., Sueper, D., Zhang, Q., Sun, Y., Trimborn, A., Northway, M., Ziemann, P. J., Canagaratna, M. R., Onasch, T. B., Alfarra, R., Prévôt, A. S. H., Dommen, J., Duplissy, J., Metzger, A., Baltensperger, U., and Jimenez, J. L.: O/C and OM/OC Ratios of Primary, Secondary, and Ambient Organic Aerosols with High Resolution Time-of-Flight Aerosol Mass Spectrometry, Environ. Sci. Technol., 42, 4478-4485, doi:10.1021/es703009q, 2008.

Aiken, A. C., Salcedo, D., Cubison, M. J., Huffman, J. A., DeCarlo, P. F., Ulbrich, I. M., Docherty, K. S., Sueper, D., Kimmel, J. R., Worsnop, D. R., Trimborn, A., Northway, M., Stone, E. A., Schauer, J. J., Volkamer, R. M., Fortner, E., de Foy, B., Wang, J., Laskin, A., Shutthanandan, V., Zheng, J., Zhang, R., Gaffney, J., Marley, N. A., Paredes-Miranda, G., Arnott, W. P., Molina, L. T., Sosa, G., and Jimenez, J. L.: Mexico City aerosol analysis during MILAGRO using high resolution aerosol mass spectrometry at the urban supersite (T0) - Part 1: Fine particle composition and organic source apportionment, Atmos. Chem. Phys., 9, 6633-6653, doi:10.5194/acp-9-6633-2009, 2009.

Alfarra, M. R., Prévôt, A. S. H., Szidat, S., Sandradewi, J., Weimer, S., Lanz, V. A., Schreiber, D., Mohr, M., and Baltensperger, U.: Identification of the Mass Spectral Signature of Organic Aerosols from Wood Burning Emissions, Environ. Sci. Technol., 41, 5770-5777, doi:5710.1021/es062289b, 2007.

Allan, J. D., Delia, A. E., Coe, H., Bower, K. N., Alfarra, M. R., Jimenez, J. L., Middlebrook, A. M., Drewnick, F., Onasch, T. B., Canagaratna, M. R., Jayne, J. T., and Worsnop, D. R.: A generalised method for the extraction of chemically resolved mass spectra from Aerodyne aerosol mass spectrometer data, J. Aerosol Sci., 35, 909-922, 2004.

Bahreini, R., Ervens, B., Middlebrook, A. M., Warneke, C., de Gouw, J. A., DeCarlo, P. F., Jimenez, J. L., Atlas, E., Brioude, J., Brock, C. A., Fried, A., Holloway, J. S., Peischl, J., Richter, D., Ryerson, T. B., Stark, H., Walega, J., Weibring, P., Wollny, A. G., and Fehsenfeld, F. C.: Organic Aerosol Formation in Urban and Industrial plumes near Houston and Dallas, TX, J. Geophys. Res., 114, D00F16, doi:10.1029/2008JD011493, 2009.

Bente, M., Adam, T., Ferge, T., Gallavadin, S., Sklorz, M., Streibel, T., and Zimmermann, R.: An on-line aerosol laser mass spectrometer with three, easily interchangeable laser based ionisation methods for characterisation of inorganic and aromatic compounds on particles, Int. J. Mass Spectrom., 258, 86-94, 2006.

Birch, M. E. and Cary, R. A.: Elemental carbon-based method for monitoring occupational exposures to particulate diesel exhaust, Aerosol Sci. Technol., 25, 221-241, 1996.

Bukowiecki, N., Dommen, J., Prévôt, A. S. H., Richter, R., Weingartner, E., and Baltensperger, U.: A mobile pollutant measurement laboratory - measuring gas and aerosol ambient concentrations with high spatial and temporal resolution, Atmos. Environ., 36, 5569-5579, 2002.

Canagaratna, M. R., Jayne, J. T., Jimenez, J. L., Allan, J. D., Alfarra, M. R., Zhang, Q., Onasch, T. B., Drewnick, F., Coe, H., Middlebrook, A., Delia, A., Williams, L. R., Trimborn, A. M., Northway, M. J., DeCarlo, P. F., Kolb, C. E., Davidovits, P., and Worsnop, D. R.: Chemical and Microphysical Characterization of Ambient Aerosols with the Aerodyne Aerosol Mass Spectrometer, Mass Spectrom. Rev., 26, 185-222, 2007. 
Cass, G. R.: Organic molecular tracers for particulate air pollution sources, TRAC-Trend. Anal. Chem., 17, 356-366, 1998.

Chirico, R., DeCarlo, P. F., Heringa, M. F., Tritscher, T., Richter, R., Prévôt, A. S. H., Dommen, J., Weingartner, E., Wehrle, G., Gysel, M., Laborde, M., and Baltensperger, U.: Impact of aftertreatment devices on primary emissions and secondary organic aerosol formation potential from in-use diesel vehicles: results from smog chamber experiments, Atmos. Chem. Phys., 10, 11545-11563, doi:10.5194/acp-10-11545-2010, 2010.

Cyrys, J., Pitz, M. Soentgen, J., Zimmermann, R., Wichmann, H. E., and Peters, A.: New measurement site for physical and chemical particle characterization in Augsburg, Germany, Epidemiology, 17, 250-251, 2006.

DeCarlo, P. F., Kimmel, J. R., Trimborn, A., Northway, M. J., Jayne, J. T., Aiken, A. C., Gonin, M., Fuhrer, K., Horvath, T., Docherty, K., Worsnop, D. R., and Jimenez, J. L.: Field-Deployable, HighResolution, Time-of-Flight Aerosol Mass Spectrometer, Anal. Chem., 78, 8281-8289, 2006.

DeCarlo, P. F., Dunlea, E. J., Kimmel, J. R., Aiken, A. C., Sueper, D., Crounse, J., Wennberg, P. O., Emmons, L., Shinozuka, Y., Clarke, A., Zhou, J., Tomlinson, J., Collins, D. R., Knapp, D., Weinheimer, A. J., Montzka, D. D., Campos, T., and Jimenez, J. L.: Fast airborne aerosol size and chemistry measurements above Mexico City and Central Mexico during the MILAGRO campaign, Atmos. Chem. Phys., 8, 4027-4048, doi:10.5194/acp-84027-2008, 2008.

Docherty, K. S., Stone, E. A., Ulbrich, I. M., DeCarlo, P. F., Snyder, D. C., Schauer, J. J., Peltier, R. E., Weber, R. J., Murphy, S. M., Seinfeld, J. H., Eatough, D. J., and Jimenez, J. L.: Apportionment of primary and secondary organic aerosols in southern California during the 2005 study 5 of organic aerosols in riverside (SOAR), Environ. Sci. Technol., 42, 7655-7662, 2008.

Favez, O., El Haddad, I., Piot, C., Boréave, A., Abidi, E., Marchand, N., Jaffrezo, J.-L., Besombes, J.-L., Personnaz, M.-B., Sciare, J., Wortham, H., George, C., and D'Anna, B.: Inter-comparison of source apportionment models for the estimation of wood burning aerosols during wintertime in an Alpine city (Grenoble, France), Atmos. Chem. Phys., 10, 5295-5314, doi:10.5194/acp-10-52952010, 2010.

Fine, P. M., Cass, G. R., and Simoneit, B. R. T.: Chemical Characterization of Fine Particle Emissions from the Fireplace Combustion of Woods Grown in the Southern United States, Environ. Sci. Technol., 36, 1442-1451, 2002.

Fine, P. M., Cass, G. R., and Simoneit, B. R. T.: Chemical Characterization of Fine Particle Emissions from the Fireplace Combustion of Wood Types Grown in the Midwestern and Western United States, Environ. Eng. Sci., 21, 387-407, 2004a.

Fine, P. M., Cass, G. R., and Simoneit, B. R. T.: Chemical Characterization of Fine Particle Emissions from the Wood Stove Combustion of Prevalent United States Tree Species, Environ. Eng. Sci., 21, 705-721. doi:10.1089/ees.2004.21.705, 2004b.

Grieshop, A. P., Logue, J. M., Donahue, N. M., and Robinson, A. L.: Laboratory investigation of photochemical oxidation of organic aerosol from wood fires 1: measurement and simulation of organic aerosol evolution, Atmos. Chem. Phys., 9, 1263-1277, doi:10.5194/acp-9-1263-2009, 2009.

Gu, J., Pitz, M., Schnelle-Kreis, J., Diemer, J., Reller, A., Zimmermann, R., Soentgen, J., Stoelzel, M., Wichmann, H.-E., Peters, A., and Cyrys, J.: Source apportionment of ambient particles:
Comparison of positive matrix factorization analysis applied to particle size distribution and chemical composition data, Atmos. Environ., 45, 1849-1857, 2011.

Hawthorne, S. B., Krieger, M. S., Miller, D. J., and Mathiason, M. B.: Collection and Quantitation of Methoxylated Phenol Tracers for Atmospheric Pollution from Residential Wood Stoves, Environ. Sci. Technol., 23, 470-475, 1989.

Hedberg, E., Johansson, C., Johansson, L., Swietlicki, E., and Brorström-Lundén, E.: Is levoglucosan a suitable quantitative tracer for wood burning? Comparison with receptor modeling on trace elements in Lycksele, Sweden, J. Air Waste Manage. Assoc., 56, 1669-1678, 2006.

Heringa, M. F., DeCarlo, P. F., Chirico, R., Tritscher, T., Dommen, J., Weingartner, E., Richter, R., Wehrle, G., Prévôt, A. S. H., and Baltensperger, U.: Investigations of primary and secondary particulate matter of different wood combustion appliances with a high-resolution time-of-flight aerosol mass spectrometer, Atmos. Chem. Phys., 11, 5945-5957, doi:10.5194/acp-11-59452011, 2011.

IPCC: Climate Change 2007 - The Physical Science Basis, Working Group I Contribution to the Fourth Assessment Report of the IPCC, Cambridge University Press, Cambridge, UK, 2007.

Jayne, J. T., Leard, D. C., Zhang, X., Davidovits, P., Smith, K. A., Kolb, C. E., and Worsnop, D. R.: Development of an Aerosol Mass Spectrometer for Size and Composition. Analysis of Submicron Particles, Aerosol Sci. Technol., 33, 49-70, 2000.

Johansson, L. S., Leckner, B., Gustavsson, L., Cooper, D., Tullin, C., and Potter, A.: Emission characteristics of modern and oldtype residential boilers fired with wood logs and wood pellets, Atmos. Environ., 38, 4183-4195, 2004.

Kim, E. and Hopke, P. K.: Comparison between Conditional Probability Function and Nonparametric Regression for Fine Particle Source Directions, Atmos. Environ., 38, 4667-4673, 2004.

Krecl, P., Ström, J., and Johansson, C.: Diurnal variation of atmospheric aerosol during the wood combustion season in Northern Sweden, Atmos. Environ., 42, 4113-4125, 2008.

Lanz, V. A., Alfarra, M. R., Baltensperger, U., Buchmann, B., Hueglin, C., and Prévôt, A. S. H.: Source apportionment of submicron organic aerosols at an urban site by factor analytical modelling of aerosol mass spectra, Atmos. Chem. Phys., 7, 1503-1522, doi:10.5194/acp-7-1503-2007, 2007.

Lanz, V. A., Alfarra, M. R., Baltensperger, U., Buchmann, B., Hueglin, C., Szidat, S., Wehrli, M. N., Wacker, L., Weimer, S., Caseiro, A., Puxbaum, H., and Prévôt, A. S. H.: Source attribution of submicron organic aerosols during wintertime inversions by advanced factor analysis of aerosol mass spectra, Environ. Sci. Technol., 42, 214-220, 2008.

Lanz, V. A., Prévôt, A. S. H., Alfarra, M. R., Weimer, S., Mohr, C., DeCarlo, P. F., Gianini, M. F. D., Hueglin, C., Schneider, J., Favez, O., D'Anna, B., George, C., and Baltensperger, U.: Characterization of aerosol chemical composition with aerosol mass spectrometry in Central Europe: an overview, Atmos. Chem. Phys., 10, 10453-10471, doi:10.5194/acp-10-10453-2010, 2010.

Lee, T., Sullivan, A. P., Mack, L., Jimenez, J. L., Kreidenweis, S. M., Onasch, T. B., Worsnop, D. R., Malm, W., Wold, C. E., Hao, W. M., and Collett, J. L.: Variation of Chemical Smoke Marker Emissions During Flaming vs. Smoldering Phases of Laboratory Open Burning of Wildland Fuels, Aerosol Sci. Technol., 44, i-v, doi:10.1080/02786826.2010.499884, 2010. 
Lohmann, U. and Feichter, J.: Global indirect aerosol effects: a review, Atmos. Chem. Phys., 5, 715-737, doi:10.5194/acp-5-7152005, 2005.

Löwel, H., Döring, A., Schneider, A., Heier, M., Thorand, B., and Meisinger, C.: The MONICA Augsburg Surveys - Basis for Prospective Cohort Studies, Gesundheitswesen, Sonderheft 1, 13-18, 2005.

McLafferty, F. W.: Mass Spectrometric Analysis, Molecular Rearrangements, Anal. Chem., 31, 82-87, doi:10.1021/ac60145a015, 1959.

Middlebrook, A. M., Bahreini, R., Jimenez, J. L., and Canagaratna, M. R.: Evaluation of Composition-Dependent Collection Efficiencies for the Aerodyne Aerosol Mass Spectrometer using Field Data, Aerosol Sci. Technol., 46, 258-271, doi:10.1080/02786826.2011.620041, 2012.

Mirivel, G., Riffault, V., and Galloo, J.-C.: Development and validation of an ultra-high-performance liquid chromatography coupled to time-of-flight mass spectrometry method to quantify benzoic acid and long-chain monocarboxylic acids $\left(\mathrm{C}_{12}-\mathrm{C}_{28}\right)$ in atmospheric aerosols, J. Chromatogr. A, 1216, 6481-6489, 2009.

Mohr, C., Huffman, J. A., Cubison, M. J., Aiken, A. C., Docherty, K. S., Kimmel, J. R., Ulbricht, I. M., Hannigan, M., and Jimenez, J. L.: Characterization of Primary Organic Aerosol Emissions from Meat Cooking, Trash Burning, and Motor vehicles with High-Resolution Aerosol Mass Spectrometry and Comparison with Ambient and Chamber Observations, Environ. Sci. Technol., 43, 2443-2449, doi:10.1021/Es8011518, 2009.

Mohr, C., Richter, R., DeCarlo, P. F., Prévôt, A. S. H., and Baltensperger, U.: Spatial variation of chemical composition and sources of submicron aerosol in Zurich during wintertime using mobile aerosol mass spectrometer data, Atmos. Chem. Phys., 11, 7465-7482, doi:10.5194/acp-11-7465-2011, 2011.

Mohr, C., DeCarlo, P. F., Heringa, M. F., Chirico, R., Slowik, J. G., Richter, R., Reche, C., Alastuey, A., Querol, X., Seco, R., Peñuelas, J., Jiménez, J. L., Crippa, M., Zimmermann, R., Baltensperger, U., and Prévôt, A. S. H.: Identification and quantification of organic aerosol from cooking and other sources in Barcelona using aerosol mass spectrometer data, Atmos. Chem. Phys., 12, 1649-1665, doi:10.5194/acp-12-1649-2012, 2012.

Orasche, J., Schnelle-Kreis, J., Abbaszade, G., and Zimmermann, R.: Technical Note: In-situ derivatization thermal desorption GC-TOFMS for direct analysis of particle-bound non-polar and polar organic species, Atmos. Chem. Phys., 11, 8977-8993, doi:10.5194/acp-11-8977-2011, 2011.

Oster, M., Elsasser, M., Schnelle-Kreis, J., and Zimmermann, R.: First field application of a thermal desorption resonanceenhanced multiphoton-ionisation single particle time-of-flight mass spectrometer for the on-line detection of particle bound polycyclic aromatic hydrocarbons. Anal. Bioanal. Chem., 401, 3173-3182, doi:10.1007/s00216-011-5438-9, 2011.

Paatero, P. and Tappert U.: Positive Matrix Factorization: a nonnegative factor model with optimal utilization of error estimated of data values, Environmetrics, 5, 111-126, 1994.

Paatero, P.: Least squares formulation of robust non-negative factor analysis, Chemometr. Intell. Lab., 37, 23-35, 1997.

Pitz, M., Birmili, W., Schmid, O., Peters, A., Wichmann, H. E., and Cyrys, J.: Quality control and quality assurance for particle size distribution measurements at an urban monitoring station in Augsburg, Germany, J. Environ. Monitor., 10, 1017-1024, 2008.
Pope, C. A. and Dockery, D. W.: Health effects of fine particulate air pollution: Lines that connect, J. Air Waste Manage. Assoc., 56, 709-742, 2006.

Puxbaum, H., Caseiro, A., Sánchez-Ochoa, A., Kasper-Giebl, A., Claeys, M., Gelencs'er, A., Legrand, M., Preunkert, S., and Pio, C.: Levoglucosan levels at background sites in Europe for assessing the impact of biomass combustion on the aerosol European background, J. Geophys. Res., 112, D23S05, doi:10.1029/2006JD008114, 2007.

Sandradewi, J., Prévôt, A. S. H., Alfarra, M. R., Szidat, S., Wehrli, M. N., Ruff, M., Weimer, S., Lanz, V. A., Weingartner, E., Perron, N., Caseiro, A., Kasper-Giebl, A., Puxbaum, H., Wacker, L., and Baltensperger, U.: Comparison of several wood smoke markers and source apportionment methods for wood burning particulate mass, Atmos. Chem. Phys. Discuss., 8, 8091-8118, doi:10.5194/acpd-8-8091-2008, 2008a.

Sandradewi, J., Prévôt, A. S. H., Weingartner, E., Schmidhauser, R., Gysel, M., and Baltensperger, U.: A study of wood burning and traffic aerosols in an Alpine valley using a multi-wavelength aethalometer, Atmos. Environ., 42, 101-112, 2008b.

Schneider, J., Weimer, S., Drewnick, F., Borrmann, S., Helas, G., Gwaze, P., Schmid, O., Andreae, M. O., and Kirchner, U.: Mass spectrometric analysis and aerodynamic properties of various types of combustion-related aerosol particles, Int. J. Mass Spectrom., 258, 37-49, 2006.

Schmidl, C., Marr, I. L., Caseiro, A., Kotianova, P., Berner, A., Bauer, H., Kasper-Giebl, A., and Puxbaum, H.: Chemical characterisation of fine particle emissions from wood stove combustion of common woods growing in mid-European Alpine regions, Atmos. Environ., 42, 126-141, 2008.

Simoneit, B. R. T.: Biomass burning - a review of organic tracers for smoke from incomplete combustion, Appl. Geochem., 17, 129162, 2002.

Sueper, D.: ToF-AMS High Resolution Analysis Software - Pika, online available at: http://cires.colorado.edu/jimenez-group/ ToFAMSResources/ToFSoftware/PikaInfo/, 2010.

Sullivan, A. P., Holden, A. S., Patterson, L. A., McMeeking, G. R., Kreidenweis, S. M., Malm, W. C., Hao, W. M., Wold, C. E., and Collett Jr., J. L.: A method for smoke marker measurements and its potential application for determining the contribution of biomass burning from wildfires and prescribed fires to ambient $\mathrm{PM}_{2.5}$ organic carbon, J. Geophys. Res., 113, D22302, doi:10.1029/2008JD010216, 2008.

Svane, M., Hagström, M., and Pettersson, J. B. C.: Chemical analysis of individual alkali-containing aerosol particles: Design and performance of a surface ionization particle beam mass spectrometer, Aerosol Sci. Technol., 38, 655-663, 2004.

Svane, M., Gustafsson, T. L., Kocevik, B., Noda, J., Andersson , P. U., Nilsson D. E., and Pettersson, J. B. C.: On-line chemical analysis of individual alkali-containing aerosol particles by surface ionization combined with time-of-flight mass spectrometry, Aerosol Sci. Technol., 43, 653-661, 2009.

Szidat, S., Prévôt, A. S. H., Sandradewi, J., Alfarra, M. R., Synal, H.-A., Wacker, L., and Baltensperger, U.: Dominant impact of residential wood burning on particulate matter in Alpine valleys during winter, Geophys. Res. Lett., 34, L05820, doi:10.1029/2006GL028325, 2007.

Turpin, B. J. and Lim, H. J.: Species contribution to PM2.5 mass concentrations: revisiting common assumptions for estimating 
organic mass, Aerosol Sci. Technol., 35, 602-610, 2001.

Ulbrich, I. M., Canagaratna, M. R., Zhang, Q., Worsnop, D. R., and Jimenez, J. L.: Interpretation of organic components from Positive Matrix Factorization of aerosol mass spectrometric data, Atmos. Chem. Phys., 9, 2891-2918, doi:10.5194/acp-9-2891-2009, 2009.

Viana, M., Kuhlbusch, T. A. J., Querol, X., Alastuey, A., Harrison, R. M., Hopke, P. K., Winiwarter, W., Vallius, M., Szidat, S., Prévôt, A. S. H., Hueglin, C., Bloemen, H., Wåhlin, P., Vecchi, R., Miranda, A. I., Kasper-Giebl, A., Maenhaut, W., and Hitzenberger, R.: Source apportionment of particulate matter in Europe: A review of method and results, J. Aerosol Sci., 39, 827-849, 2008.

Zhang, Q., Alfarra, M. R., Worsnop, D. R., Allan, J. D., Coe, H., Canagaratna, M. R., and Jimenez, J. L.: Deconvolution and quantification of hydrocarbon-like and oxygenated organic aerosols based on aerosol mass spectrometry, Environ. Sci. Technol., 39, 4938-4952, 2005.
Zhang, T., Claeys, M., Cachier, H., Dong, S., Wang, W., Maenhaut, W., and Liu, X.: Identification and estimation of the biomass burning contribution to Beijing aerosol using levoglucosan as a molecular marker, Atmos. Environ., 42, 7013-7021, 2008.

Zhang, X., Smith, K. A., Worsnop, D. R., Jimenez, J. L., Jayne, J. T., and Kolb, C. E.: A Numerical Characterization of Particle Beam Collimation by an Aerodynamic Lens-Nozzle System Part I: An Individual Lens or Nozzle, Aerosol Sci. Technol., 36, 617-631, 2002.

Zhang, X., Smith, K. A., Worsnop, D. R., Jimenez, J. L., Jayne, J. T., Kolb, C. E., Morris, J., and Davidovits, P.: Numerical Characterization of Particle Beam Collimation - Part II: Integrated Aerodynamic Lens-Nozzle System, Aerosol Sci. Technol., 38, 619-638, 2004. 